\title{
Transforming Servant Leadership, Organizational Culture, Change, Sustainability, and Courageous Leadership
}

\author{
David C. Stauffer \\ Ancilla College \\ Delois L. Maxwell \\ St. Thomas University
}

This study examined the role of Transforming Servant Leadership in organizational change, culture, and sustainability. A sample of one hundred twenty-five (125) administrators, staff, and faculty in a small midwestern college responded to a questionnaire designed to address the relationship of Transforming Servant Leadership Attitudes and Behaviors, to Organizational Culture and Change Strategies. Results indicate leadership attitudes that positively correlate to change strategies should be supported by leadership behaviors, and organizational culture is a dynamic reflective of leadership related to change strategies. The study provides a foundation to understand Transforming Servant Leadership in courageous and ethical change management.

Keywords: transforming servant leadership, change management, sustainable leadership, organizational culture, courageous leadership

\section{INTRODUCTION}

The subject of change is one that every organization faces on a regular basis. It carries with it the risk of failure and the opportunity to advance (Nelson \& Quick, 2015). Change is a broad and deep subject. It is a topic that without exception impacts individuals, organizations, economies, and societies (Kinicki \& Williams, 2018). In many cases, the success or failure of an organization correlates with the effectiveness of leadership and the ability to embrace the need for change (Williams, 2015). Problems are a reality in both for-profit and not-for-profit organizational settings. Maxwell (2013) indicated that change is scary and hard because it requires the tossing aside of the familiar to jump headlong into the unknown. Moreover, change can be rife with failure until discovering the right mix to chart a new course for success. Simply stated, change is inevitable, and it requires effective and courageous leadership. However, change can be the catalyst to turn possibilities into reality (Maxwell, 2013).

This research examines the role of transforming servant leadership in organizational change. The focus of this research is on the stakeholders in a small private college that is struggling to remain open due to several factors including challenges with leadership. The college has had difficulty in recent years with enrollment and historically has not developed productive relationships and partnerships with alumni, community leaders, and organizations in the marketplace. The methodology of this research study is 
quantitative to describe and answer important questions about the influence of transforming servant leadership attributes among internal and external stakeholders connected to the school.

According to Craig (2017), higher education enrollment patterns are problematic, and an increasing number of colleges will experience declining revenues. Declining revenue is particularly the case for smaller colleges outside of the large urban areas (Craig, 2017). While wealthy and famous institutions of higher education are experiencing unprecedented success, this is not the norm for smaller colleges. The average private college's net revenue has remained flat over the last decade (College Board, 2017). According to Clark (2015), small, rural colleges serving small communities, appear to be facing the most difficult challenges to recruit an adequate number of students to survive. Recruiting issues are multifaceted which is underscored by Keller who stated, "Like small and large business firms, the country's thirty-nine hundred colleges and universities are expected to scramble, strategize, and compete for students, professors, facilities, acclaim, and financial stability. If they do not, they are likely to close their doors or be closed" (Keller, 2004, p. xi).

\section{PROBLEM STATEMENT}

There is limited research that examines to what extent the philosophy and practice of servant leadership as a transformational strategy will influence organizational change. The problem addressed by this quantitative study is the sustainability of a small private college. In the last decade, a small private Catholic, two-year liberal arts institution of higher education referred to in this study as Faith College (pseudonym), located in the Midwest, has faced many challenges to its sustainability. Decreased student enrollment, eroding student retention, and reduced new student inquiries and applications are threatening the institution's survival (Faith College, 2017). Furthermore, a lack of team cohesiveness between the major departments such as staff, academics, finance, enrollment management, athletics, and marketing has hindered the operational effectiveness of the organization (Faith College, 2016-2017). Additionally, Town Hall meetings with community leaders indicate a desire by external stakeholders to partner with the college in a collaborative effort to develop market-driven programs and a sense of community. The issues contributing to this problem are complex and multi-layered including enrollment, retention, operational effectiveness, and partnership development.

Effective leadership is required to initiate and sustain organizational change (Williams, 2015). For the success of an organization concerning change, it is necessary for it to adopt an effective leadership approach (Tuncer, 2011). A lack of active leadership involvement reduces the possibility of navigating and adapting to change (Saylı \& Tüfekçi, 2008). Servant leadership traits practiced by college administrators and faculty could improve eroding student retention, bring together the friction between departments, and develop a sense of community with external stakeholders because servant leaders place the well-being of others above that of their own (Rush, 1989).

While there are many leadership models, the concept of servant leadership is relatively new and limited (McShane \& Von Glinow, 2014). Robert Greenleaf first introduced servant leadership less than five decades ago (Greenleaf, 2016). Scholarly interest in this topic has increased in recent years, but the concept faces many conceptual challenges and lacks agreement among researchers (McShane \& Von Glinow, 2014). Consequently, with limited empirical research on servant leadership, an opportunity exists for further study to see whether there is a relationship between servant leadership attributes with organizational predictors and outcomes.

Research on servant leadership and organizational change in a small private college will contribute to an understanding of this leadership practice in a higher education context. Therefore, the problem is worthy of further investigation because, without significant changes, the struggling college is on a path leading to a battle for its survival. Furthermore, the study could provide a baseline of information to benefit other struggling organizations, particularly in the private college and K-12 educational context. 


\section{IMPORTANCE OF THE RESEARCH}

Today's global economy has organizations fighting for survival (Frynas \& Mellahi, 2015). Small, private, tuition-driven colleges and universities have struggled for decades to become financially viable and sustainable (Breneman, 1994; Townsley, 2002). Challenges confronting colleges continue with macroeconomic stresses, increased enrollment pressures from shifting high school graduation patterns, demographic changes, technological advances in educational delivery, and changing economic conditions (Breneman, 1994; Keller, 1983; Martin \& Samels, 2009; Spanier, 2010). Small tuition-driven private colleges are especially susceptible to these issues (Keller, 2004; Townsley, 2002). The design of this research project is to gain insight and understand the influence of transforming servant leadership principles on a struggling organization in need of change.

If struggling organizations are to survive and thrive, they must address performance outcome issues and leadership methods. Recognizing the stressors faced by struggling organizations and developing pathways to improve are critical steps to overcome them (Wells, 2018; Winstanley \& Stuart-Smith, 1996). There is limited research that examines to what extent the philosophy and practice of servant leadership as a transformational method will influence organizational change.

Effective leadership is required to initiate and sustain organizational change (Tuncer, 2011). Servant leadership traits embraced and practiced by college administrators, staff, and faculty members could improve many performance outcomes that are vital indicators contributing to the struggles of the college (McShane \& Von Glinow, 2014; Xenikou \& Simosi, 2006). Results of this study should be beneficial to small, tuition-driven institutions, and other organizations facing an institutional crisis. The practical significance of this study is that management can learn a framework for understanding a leadership model to influence change for struggling organizations.

\section{THEORY FRAMING THE STUDY}

Concepts from Servant Leadership Theory serve as the theoretical framework for the current study (Greenleaf, 1977). The presumption is that traits, attitudes, and behaviors of Servant Leadership represent transformational strategies practiced by college leadership functioning as administrators, faculty, and staff. The focus of this research is on the leadership functioning as administrators, faculty, and staff in a small private college that is struggling to remain open due to inadequate performance outcomes requiring organizational change. This approach could have a positive impact on essential organizational performance outcomes such as student enrollment, student retention, departmental teamwork, culture, and community relations with external stakeholders. The study utilizes a quantitative cross-sectional survey methodology to describe and answer important questions about the influence of transforming servant leadership attributes among leadership connected to the school. Three key variables associated with this study include transforming servant leadership, organizational change strategies, and organizational culture.

Robert Greenleaf first introduced the concept of servant leadership five decades ago (Greenleaf: Center for Servant Leadership, 2016). Since its introduction, servant leadership has experienced a steady following especially among practitioners and religious leaders. Scholarly interest in this topic has grown substantially, but the theory still faces some conceptual challenges (McShane \& Von Glinow, 2014). According to Greenleaf (1977), meeting the needs of followers drives servant leaders, along with ensuring the enhancement of their well-being, in addition to providing attention to the less fortunate in society.

James MacGregor Burns (1978) first introduced the concept of transforming leadership and later established the idea of transactional leadership. Burns (1978) theorized that transactional leaders work within the existing culture in an organization, whereas transforming leaders seek to influence the organizational culture. Bernard M. Bass (1985), furthered the work of Burns (1978) by underscoring the psychological mechanisms associated with transforming and transactional leadership; additionally, Bass used the term "transformational" instead of "transforming." Transformational leadership views leaders as change agents (McShane \& Von Glinow, 2014). Transformational leaders create a more adaptive culture, 
which in turn increases organizational performance (Xenikou \& Simosi, 2006). Transformational leadership is an approach that causes a change in individuals and social systems (Burns, 1978). It creates valuable and positive change in followers with the goal of developing them into leaders, which enhances motivation, morale, and performance (Burns, 1978).

Transforming Servant Leadership is a new concept that combines the principles of servant leadership focused on benefits to followers with transformational leadership focused on the leader's influence on motivation and organizational performance. Combining the strengths of both concepts to offset the weaknesses or voids is the framework for the new concept. Consequently, the operational definition of Transforming Servant Leadership (TSL) is the process of serving to enhance the vision, values, and vitality of individuals, groups, and organizations (Burns, 1978; Bass, 1997; Greenleaf, 1977; Patterson, 2003).

Today, there are significant factors that motivate and require organizations to change; therefore, it is incumbent upon organizations to change (İkinci, 2014). A significant development in the concept of organizational change is a growing emphasis on corporate culture as the element that holds a firm together and gives it direction (Kinicki \& Williams, 2018). Schein (1996) referred to organizational culture as the set of shared, sometimes taken-for-granted, implied assumptions that are held and determine how it perceives, thinks about and reacts to its many environments.

Servant leadership is a relatively new but emerging paradigm of leadership. Greenleaf's (1977) seminal work with this leadership approach is foundational for further development of the theory.

Spears (1995) offered a framework that is not an exhaustive list of servant leadership characteristics, but depicts ten of the most common identified in literature as follows.

1. Focus on listening

2. Ability to empathize with the feelings of others

3. Focus on healing suffering from broken spirits and emotional hurts

4. Self-awareness of strengths and weaknesses

5. Use of persuasion rather than positional authority to influence others

6. Broad-based conceptual thinking and vision

7. Ability to project and foresee future outcomes

8. Embrace a stewardship approach to leadership of people and resources

9. Commitment to the growth of people

10. Drive to build community inside and outside the organization (pp. 1-14)

According to Spears (1995), the ten characteristics of servant leadership consistently displayed provide happier, more creative, and more productive employees. There are many research studies on servant leadership in a variety of organizational settings such as athletics, sales, military, education, conflict management, and publicly traded companies (Greenleaf, 2016).

Laub (1999) defined servant leadership with behavioral characteristics. Braye (2000) researched servant leadership and compared executive leadership of female and male leaders and concluded that women leaders have a more natural affiliation toward the characteristics of servant leadership, which might be advantageous. Herbert (2003) researched servant leadership focused on both intrinsic and extrinsic job satisfaction. Drury (2004) investigated a correlation between servant leadership, job satisfaction, and organizational loyalty. Irving (2005) conducted research that measured servant leadership and team effectiveness and found a statistically significant correlation. In addition to research studies, leading multi-million and multi-billion dollar companies have found success by embracing servant leadership within their cultures such as Southwest Airlines, TDIndustries, Synovus Financial Corporation, Starbucks, and Kimpton Hotels \& Restaurants (Ruschman, 2002; Chen, Zhu, \& Zhou, 2015; Giang, 2016).

Interest in servant leadership theory continues to advance. However, the empirical research to-date only measures the perceptions of self and follower relative to servant leadership effectiveness. There is a need for this research as an emerging leadership paradigm, and there appears to be a void for more quantitative and qualitative analysis that connects servant leadership with organizational change and improved outcomes (Hannigan, 2008). 
Studies have revealed the use and success of transformational leadership in a wide range of occupational, organizational, and cultural settings such as the military, schools, and corporations (Bryant, 2003). Research by Carlson and Perrewe (1995) indicated that transformational leadership is a catalyst when an organization needs significant changes to its mission and strategic management. A study by Bryant (2003) showed that transformational leadership produces above-average results under conditions of crisis and uncertainty. Odom and Green (2003) researched numerous legal cases and discovered that principles of transformational leadership applied to ethical dilemmas offer less litigation and superior moral outcomes. In a recent study of culture in Taiwan and the United States, Spreitzer, Perttula, and Xin (2005) established that the effectiveness of transformational leadership correlates to cultural values. In educational settings, research indicates that transformational leadership teachers are more likely to collaborate, be open to change, and have positive attitudes (Hay, 2006).

Despite the numerous characteristics, uses, and positive outcomes of transformational leadership, it is not without its criticisms. The morality of this leadership approach due to the potential for the abuse of power has been questioned and criticized (Mason, Griffin, \& Parker, 2014; Hall, Johnson, Wysocki, \& Kepner, 2002). The potential for the development of unhealthy leader-follower dependency is another criticism (Stone, Russell, \& Patterson, 2003). Bass (1997) noted that transformational leadership lacks accountability measures to avoid a dictatorial and oppressive leadership approach and further indicated that transformational leadership lends itself toward self-promotion due to its close association with charismatic and impressive management. Based on research, there appears to be an opportunity to connect the selfless leadership approach of servant leadership theory with transformational leadership theory to fill and counter the risks associated with an overly aggressive leadership approach and self-promotion that can surface with transformational leadership.

Effective leadership is required to initiate and sustain organizational change (Williams, 2015). For an organization to change successfully, it is necessary for it to adopt an effective leadership approach (Tuncer, 2011). Therefore, the development of the theoretical framework for this study is to examine the influence of Transforming Servant Leadership on Organizational Change Strategies and Organizational Culture, with Organizational Culture as an intermediary variable.

\section{RESEARCH QUESTIONS}

The design of the following research questions/hypotheses guide this study and are to examine the level of servant leadership attributes among staff and faculty in an educational setting.

Journal of Leadership, Accountability and Ethics Vol. 17(1) 2020109 


\section{FIGURE 1}

\section{CONCEPTUAL/TESTED MODEL OF TRANSFORMING SERVANT LEADERSHIP, ORGANIZATIONAL CULTURE, AND ORGANIZATIONAL CHANGE STRATEGIES}

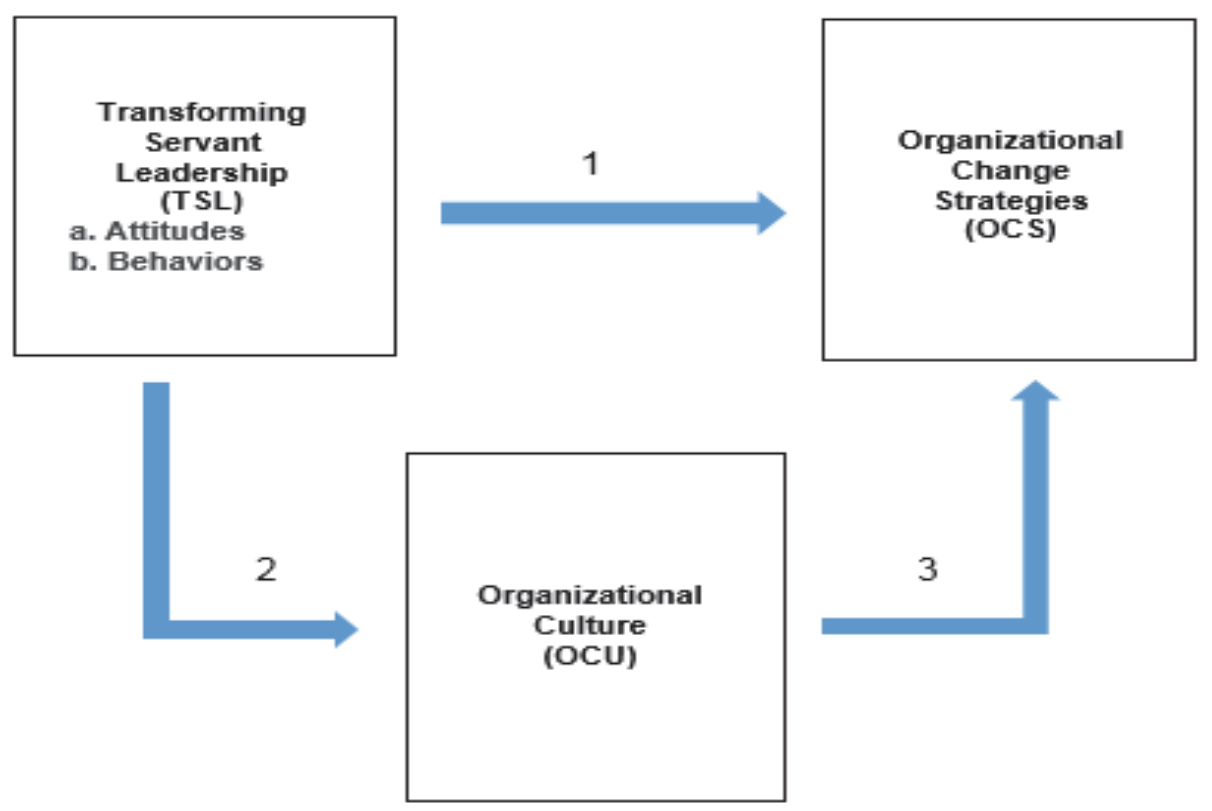

As depicted in Figure 1, the following research questions represent the relationships tested in the study.

$\mathrm{R}_{1}$ : What is the relationship of Transforming Servant Leader (TSL) Attitudes to Organizational Change Strategies (OCS)?

$\mathrm{H}_{10^{-}}$There is no difference in the relationship of Transforming Servant Leader (TSL) Attitudes to Organizational Change Strategies (OCS).

$\mathrm{H}_{1}$ : There is a difference in the relationship of Transforming Servant Leader (TSL) Attitudes to Organizational Change Strategies (OCS).

$\mathrm{R}_{2}$ : What is the relationship of Transforming Servant Leader (TSL) Behaviors to Organizational Change Strategies (OCS)?

$\mathrm{H}_{20^{-}}$There is no difference in the relationship of Transforming Servant Leader (TSL) Behaviors to Organizational Change Strategies (OCS).

$\mathrm{H}_{2}$ : There is a difference in the relationship of Transforming Servant Leader (TSL) Behaviors to Organizational Change Strategies (OCS).

$\mathrm{R}_{3}$ : What is the relationship of Transforming Servant Leader (TSL) Attitudes to Organizational Culture (OCU)?

$\mathrm{H}_{30^{-}}$There is no difference in the relationship of Transforming Servant Leader (TSL) Attitudes to Organizational Culture (OCU).

$\mathrm{H}_{3}$ : There is a difference in the relationship of Transforming Servant Leader (TSL) Attitudes to Organizational Culture (OCU).

$\mathrm{R}_{4}$ : What is the relationship of Transforming Servant Leader (TSL) Behaviors to Organizational Culture (OCU)?

$\mathrm{H}_{40}$ - There is no difference in the relationship of Transforming Servant Leader (TSL) Behaviors to Organizational Culture (OCU).

$\mathrm{H}_{4}$ : There is a difference in the relationship of Transforming Servant Leader (TSL) Behaviors to Organizational Culture (OCU). 
$\mathrm{R}_{5}$ : What is the relationship of Organizational Culture (OCU) to Organizational Change Strategies (OCS)?

$\mathrm{H}_{50^{-}}$There is no difference in the relationship of Organizational Culture (OCU) to Organizational Change Strategies (OCS).

$\mathrm{H}_{5}$ : There is a difference in the relationship of Organizational Culture (OCU) to Organizational Change Strategies (OCS).

Three general concepts guide this study related to change. One concept involves the attitudes and behaviors of Transforming Servant Leadership (TSL) and their influence on Organizational Change Strategies (OCS). Another concept applies to the impact of Transforming Servant Leadership (TSL) on Organizational Culture (OCU). A third concept relates to the influence of Organizational Culture on Organizational Change Strategies.

\section{METHODOLOGY}

This study employs a quantitative approach designed to examine the level to which administration, staff, and faculty in a small two-year college possess the attitudes and behaviors that promote the philosophy of servant leadership as a transformational method for leading. Servant leadership is a relatively new but emerging paradigm of leadership (Greenleaf, 1977). Therefore, this quantitative approach is also an exploratory study to investigate an area where additional research is needed (Kerlinger \& Lee, 2000; Hannigan, 2008; Kumar, 2014). The development of the study is to answer questions about a relationship between Transforming Servant Leadership Attitudes and Behaviors, Organizational Change Strategies, and Organizational Culture. This study uses a correlational design to examine relationships among variables, and as such, it does not demonstrate causality; however, the findings of this study may provide information and rationale for additional research that investigates a correlation between Transforming Servant Leadership with Organizational Change Strategies and improved organizational performance outcomes (Hannigan, 2008; Kumar, 2014; Creswell, 2014).

Characteristics of the persons involved in the study include the following: (a) gender: female and male, (b) race: Caucasian and African American, (c) ethnicity: American, Hispanic, Canadian, Latino, and Asian. The education levels include associate, bachelor, master, and doctoral degrees. The experience level ranges from less than one year to 27-years of tenure. The classification of the target population is middle-class when considering various socioeconomic factors (Shavers, 2007; Leventoglu, 2014). A full description of the target population is not available due to matters of anonymity and confidentiality. The sample for this study consists of those 80 individuals from the target population who submitted responses to the questionnaire. The sample includes 20 individuals in an administrative leadership role, 29 individuals in a staff role, and 31 individuals in a faculty role.

This study utilizes an existing instrument to collect data with the Organizational Leadership Assessment (OLA) administered electronically (Laub, 1998). Dr. Jim Laub, the founder of the OLAGroup, developed the OLA to assess the health of organizations through a comprehensive research project that produced a detailed model of servant leadership applied to organizational life. The development of the OLA came through a Delphi Survey process utilizing a panel of 14 experts in the field of servant leadership (Laub, 2000). These experts included Jim Kouzes from Learning Systems, Inc., The Tom Peters Group and Larry Spears from the Greenleaf Center for Servant Leadership along with twelve others who had published or taught at the university level on the subject of servant leadership (Laub, 2000). The Delphi is a process used to obtain consensus from group experts in an applied field by providing facilitated, but individual responses to questions (Robson, 2002; Hannigan, 2008; Laub, 2000). Through a three-part Delphi process, these experts came to a consensus on the characteristics of the servant-minded organization. The experts clustered the characteristics into six key areas as follows: values people, builds community, develops people, displays authenticity, provides leadership, and shares leadership (Laub, 2000). 
Data for this study is analyzed using the Statistical Package for Social Sciences (SPSS) software version 25. Composite variables are developed using SPSS Reliability Analysis procedures to generate a Cronbach's Alpha Coefficient. The composite variables include Transforming Servant Leadership (TSL) Attitudes and Behaviors, Organizational Change Strategies (OCS), and Organizational Culture (OCU). Transforming Servant Leadership (TSL) Attitudes and Behaviors serve as the independent variable, Organizational Change Strategies (OCS) as the dependent variable, and Organizational Culture (OCU) as the intermediary variable. The variables were developed into composites using items from the OLA questionnaire as noted below.

TSL Attitudes - A leader's disposition that reflects openness and honesty about what he or she says and means; humbleness about limitations and mistakes; and influence by positive and personable relations.

TSL Behaviors - A leader that is courageous and visionary; action oriented and accountable; listens and learns; put needs of others first; and empower, encourage and affirm others.

Organizational Culture - An environment that is goal oriented, focused, and accountable; where individuals share a set of values and norms that reflect trust, respect, and concern for others; and engage in teamwork.

Organizational Change Strategies - A leader's behavior or action that promote organizational change by allowing workers to help determine direction, encouraging a learning environment, and team building; encouraging open communication and sharing of information; and taking risks, and appropriate action when needed.

The first step in the analysis is to generate descriptive statistics to summarize and examine trends in the data. The next step involves generating a Pearson $r$ Correlation and bivariate analysis. Assumptions to test for the Pearson $r$ correlation include normality, linearity, and homoscedasticity.

\section{FINDINGS}

The proliferation of leadership literature and leadership styles make it difficult for leaders to practice (Hussain \& Hassan, 2016). In recent years, several methods or categories of leadership have emerged in the literature such as autocratic, participative, and entrepreneurial (Pride, Hughes, \& Kapoor, 2017). However, most management experts indicate that no best managerial leadership style exists for every individual and every setting (Pride et al., 2017). When considering the traditional view of leadership, descriptions include characteristics related to experience, education, qualification, and ability to produce results; however, there are numerous leadership typologies (İkinci, 2014). From this perspective, a transformative leadership approach draws interest due to the changes and developments in today's management and leadership theories and applications (Eraslan, 2014).

Transforming Servant Leadership (TSL) is a new concept that combines the principles of servant leadership focused on benefits to followers with transformational leadership focused on the leader's influence on motivation and organizational performance (Burns, 1978; Bass, 1997; Greenleaf, 1977; Patterson, 2003). Additionally, any benefits received by the Transforming Servant Leader are an overflow of the outcomes produced by the leader, not due to self-promotion. Consequently, this study's focus is on both the Attitudes and Behaviors of Transforming Servant Leadership (TSL) and reveal a strong positive correlation for both with change strategies and culture. Therefore, the research findings from this study confirm the assumptions or expectations of the conceptual framework of this study and the literature concerning effective change management, the relationship of leadership, and the value of organizational culture.

This study contends that a relationship exists between Transforming Servant Leadership (TSL) Attitudes and Behaviors, Organizational Change Strategies (OCS) and Organizational Culture (OCU). This study also contends that a relationship exists between Organizational Culture (OCU) and Organizational Change Strategies (OCS). Results of the study reveal a statistically significant relationship between Transforming Servant Leadership (TSL) Attitudes and Behaviors, Organizational Change 
Strategies (OCS), and Organizational Culture (OCU) with a Pearson r correlation range between .81 and 93. The internal consistency and reliability for each composite based on a Cronbach's Alpha score of equal to or greater than .92 underscore various elements of each composite. The results for each research question are as follows:

$\mathrm{R}_{1}$ : What is the relationship of Transforming Servant Leader (TSL) Attitudes to Organizational Change Strategies (OCS)?

Research results for the first research question indicate statistical significance as depicted by a Pearson $r$ of .90. There is a strong positive relationship between Transforming Servant Leadership (TSL) Attitudes and Organizational Change Strategies (OCS); therefore, the results reject the null hypothesis.

$\mathrm{R}_{2}$ : What is the relationship of Transforming Servant Leader (TSL) Behaviors to Organizational Change Strategies (OCS)?

Research results for the second research question indicate statistical significance as depicted by a Pearson $r$ of .93. The strongest positive relationship for this study is between Transforming Servant Leadership (TSL) Behaviors and Organizational Change Strategies (OCS); therefore, the results reject the null hypothesis.

$\mathrm{R}_{3}$ : What is the relationship of Transforming Servant Leader (TSL) Attitudes to Organizational Culture (OCU)?

Research results for the third research question indicate statistical significance as depicted by a Pearson $r$ of .82. There is a strong positive relationship between Transforming Servant Leadership (TSL) Attitudes and Organizational Culture (OCU); therefore, the results reject the null hypothesis.

$\mathrm{R}_{4}$ : What is the relationship of Transforming Servant Leader (TSL) Behaviors to Organizational Culture (OCU)?

Research results for the fourth research question indicate statistical significance as depicted by a Pearson $r$ of .81. There is a strong positive relationship between Transforming Servant Leadership (TSL) Behaviors and Organizational Culture (OCU); therefore, the results reject the null hypothesis.

$\mathrm{R}_{5}$ : What is the relationship of Organizational Culture (OCU) to Organizational Change Strategies (OCS)?

Research results for the fifth research question indicate statistical significance as depicted by a Pearson $\mathrm{r}$ of .81. There is a strong positive relationship between Organizational Culture (OCU) and Organizational Change Strategies (OCS); therefore, the results reject the null hypothesis.

This study's research results indicate that leadership in general, and more specifically the attitudes and behaviors of leadership are related to change strategies and culture in organizational management. Furthermore, organizational culture is a dynamic reflective of leadership that is related to change strategies in organizational management. This study's research also indicates that the behaviors of a leader are no less important than the attitudes of a leader.

\section{SUMMARY AND CONCLUSION}

The literature supports the need for organizations to change due to the demands of the marketplace, the importance of leadership, and the value of organizational culture. The following suggested implications are for practice.

First Implication. The first implication for this study is that an organization can use a servant leadership instrument (OLA) to evaluate Transforming Servant Leadership (TSL) as a new concept. The literature explains the concepts of servant leadership and transformational leadership (Burns, 1978; Bass, 1997; Greenleaf, 1977; Patterson, 2003). Combining the two concepts is a new leadership concept with a threefold focus on followers, organizations, and leaders. However, the scope of this study does not include outside stakeholders such as vendors, suppliers, and local businesses or other stakeholders such as students and parents. Furthermore, when considering various socioeconomic factors, this study does not include respondents from lower class or upper-class socioeconomic settings. As such, expanding the scope of the study beyond a single organization to different organizational settings of size and concept could provide additional research-based insights on the concept for practice. 
Second Implication. This study contributes to the studies of leadership, change strategies, and organizational culture theory. The focus of this study is on both the Attitudes and Behaviors of Transforming Servant Leadership (TSL) and found a strong positive correlation for both with change strategies and culture; however, it does not establish cause and effect, but only a relationship between factors. Therefore, a plausible implication for practice from this study is to develop a leadership-training program based on the characteristics of Transforming Servant Leadership (TSL) Attitudes and Behaviors established in this study. Conducting leadership training for implementing the practice of Transforming Servant Leadership (TSL) Attitudes and Behaviors could influence the development of successful change strategies and enhance the health of applicable organizational cultures.

Leadership and culture matter in today's world and are critical elements in organizations struggling for sustainability. Organizations with high standards and expectations, coupled with courageous, ethical, and people-centered leadership are in high demand. The challenges and opportunities of today's highly competitive, global economy place effective change management at a premium. The concept of Transforming Servant Leadership (TSL), when understood and applied in practice, serves to enhance the vision, values, and vitality of a diverse range of individuals, groups, and organizations.

Transforming servant leadership has important implications for promoting and supporting organizational change and sustainability within a fast-changing, highly contextualized global economy. Dr. Martin Luther King, Jr. stated, "Life's most persistent and urgent question is, 'What are you doing for others?". The transforming servant leader's response is a philosophy and behavior demonstrating sensitivity to and respect for the diverse needs of others. These transforming servant leaders are courageous and clearly needed in today's context of global turbulence.

\section{REFERENCES}

Bass, B. M. (1985). Leadership and performance. New York, NY: Free Press.

Bass, B. M. (1997). The ethics of transformational leadership. KLSP: Transformational Leadership, Working Papers. Retrieved from http://www.academy.umd.edu/publications/klspdocs/bbass_pl.htm

Braye, R. H. (2000). Servant-leadership: Belief and practice in women-led businesses (Doctoral dissertation). Available from ProQuest Dissertations and Theses database. (UMI No. 9981536)

Breneman, D. W. (1994). Liberal arts colleges: Thriving, surviving or endangered? Washington, D.C.: Brookings Institution Press.

Bryant, S. E. (2003). The role of transformational and transactional leadership in creating, sharing and exploiting organizational knowledge. Journal of Leadership and Organizational Studies, 9(4), 32-44.

Burns, J. M. (1978). Leadership. New York, NY: Harper \& Row.

Carlson, D. S., \& Perrewe, P. L. (1995). Institutionalization of organizational ethics through transformational leadership. Journal of Business Ethics, 14(10), 829-839.

Chen, Z., Zhu, J., \& Zhou, M. (2015, March). How does a servant leader fuel the service firm? A multilevel model of servant leadership, individual self identity, group competition climate, and customer service performance. Journal of Applied Psychology, 100(2), 511-521.

Clark, K. (2015, March 04). Some small private colleges are facing a "death spiral." Money. Retrieved from http://time.com/money/3731250/sweet-briar-private-college-death-spiral/

College Board. (2017). Trends in higher education. Retrieved from https://trends.collegeboard.org/college-pricingeath

Craig, R. (2017, January 20). The top 10 higher education issues we all agree on. Forbes. Retrieved from https://www.forbes.com/sites/ryancraig/2017/01/20/the-top-10-higher-education-issues-we-allagree-on/2/\#5b7dfd4730d0

Creswell, J. W. (2014). Research design: Qualitative, quantitative, and mixed methods approaches (4th ed.). Los Angeles, CA: Sage Publications, Inc. 
Drury, S. L. (2004). Servant leadership and organizational commitment: Empirical findings and workplace implications. Virginia Beach, VA: School of Leadership, Regent University.

Eraslan, L. (2014). A post-modern paradigm in leadership: Transformational leadership. Journal of International Human Sciences, 1(1), 1-32.

Faith College. (2017). Fact book: Exhibits of performance and analytics. Midwest: Author.

Faith College. (2016-2017). Faculty-staff data form. Midwest: Author.

Frynas, J., \& Mellahi, K. (2015). Global strategic management (3rd ed.). New York, NY: Oxford University Press.

Giang, V. (2016, June 3). The pros and cons of new unconventional leadership styles. Retrieved from http://www.fastcompany.com

Greenleaf, R. K. (1977). Servant leadership: A journey into the nature of legitimate power and greatness. New York, NY: Paulist Press.

Greenleaf, R. K. (2016). Center for servant leadership. Retrieved from https://www.greenleaf.org/what-isservant-leadership/

Hall, J., Johnson, S., Wysocki, A., \& Kepner, K. (2002). Transformational leadership: The transformation of managers and associates. Retrieved from http://edis.ifas.ufl.edu/

Hannigan, J. B. (2008). Leadership in higher education: An investigation of servant leadership as a predictor of college performance (Doctoral dissertation). Available from ProQuest Dissertations and Theses database. (UMI No. 3296726)

Hay, I. (2006). Transformational leadership: Characteristics and criticisms. E-Journal of Organizational Learning, 5(2). Retrieved from http://www.weleadinlearning.org/ejournal.htm

Herbert, S. C. (2003). The relationship of perceived servant leadership and job satisfaction from the follower's perspective (Doctoral dissertation). Available from ProQuest Dissertations and Theses database. (UMI No. 3112981)

Hussain, M., \& Hassan, H. (2016). The leadership styles dilemma in the business world.International Journal of Organizational Leadership, 5(4), 411-425.

İkinci, S. S. (2014). Organizational change: Importance of leadership style and training. Management of Organizational Studies, 1(2), 122-127.

Irving, J. A. (2005). Servant leadership and the effectiveness of teams (Doctoral dissertation). Available from ProQuest Dissertations and Theses database. (UMI No. 3173207)

Keller, G. (1983). Academic strategy: The management revolution in higher education. Baltimore: The Johns Hopkins University Press.

Keller, G. (2004). Transforming a college: The story of a little-known college's strategic climb to national distinction. Baltimore, MA: The John Hopkins University Press.

Kerlinger, F. N., \& Lee, H. B. (2000). Foundations of behavioral research (4th ed.). Stamford, CT: Wadsworth-Thomson Learning.

Kinicki, A., \& Williams, B. K. (2018). Management: A practical introduction (8th ed.). New York, NY: McGraw-Hill.

Kumar, R. (2014). Research methodology: A step-by-step guide for beginners (4 ${ }^{\text {th }}$ ed.). Los Angeles, CA: Sage Publications, Inc.

Laub, J. A. (1998). Organizational leadership assessment. Marion, IN: OLA Group. Retrieved from https://www.servantleaderperformance.com/ola/instrument/

Laub, J. A. (1999). Assessing the servant organization: Development of the servant organizational leadership assessment (SOLA) instrument (Doctoral dissertation). Available from ProQuest Dissertations and Theses database. (UMI No. 9921922)

Laub, J. A. (2000). Development of the organizational leadership assessment (OLA) instrument. OLAGroup. Retrieved from olagroup.com

Leventoğlu, B. (2014). Social Mobility, Middle Class, and Political Transitions. The Journal of Conflict Resolution, 58(5), 825-864.

Martin, J., \& Samels, J. E. (2009). Turnaround: Leading stressed colleges and universities to excellence. Baltimore: Johns Hopkins University Press. 
Mason, C., Griffin, M., \& Parker, S. (2014). Transformational leadership development: Connecting psychological and behavioral change. Leadership \& Organization Development Journal, 35(3), 174-194.

Maxwell, J. (2013, March 5). Change. Success magazine. Retrieved from http://www.success.com/article/john-c-maxwell-change

McShane, S. L., \& Von Glinow, M. A. (2014). Organizational behavior (2nd ed.). New York, NY: McGraw-Hill.

Nelson, D. L., \& Quick, J. C. (2015). ORGB: Organizational behavior. Stamford, CT: Cengage Learning.

Odom, L., \& Green, M. T. (2003). Law and the ethics of transformational leadership. Leadership and Organization Development Journal, 24(1/2), 62-69.

Patterson, K. A. (2003). Servant leadership: A theoretical model (Doctoral dissertation). Available from ProQuest Dissertations and Theses database. (UMI No. 305234239)

Pride, W. M., Hughes, R. J., \& Kapoor, J. R. (2017). Foundations of business (5th ed.). Boston, MA: Cengage Learning.

Robson, C. (2002). Real world research: A resource for social scientists and practitioner-researchers (2nd ed.). Malden, MA: Blackwell Publishing.

Rush, M. (1989). The new leader: A revolutionary approach to effective leadership. Wheaton, IL: Victor Books.

Ruschman, N. L. (2002). Servant-leadership and the best companies to work for in America. In L. C. Spears \& L. C. Lawrence (Eds.), Focus on leadership: Servant- leadership for the twenty-first century, 123-140. New York, NY: John Wiley and Sons.

Sayl, H., \& Tüfekçi, A. (2008). The role of a transformational leader in making a successful organizational change. Erciyes University, Journal of Economics and Administrative Sciences Faculty, 30, 193-210.

Schein, E. H. (1996, June). Culture: The missing concept in organizational studies. Administrative Science Quarterly, 41(2), 236.

Shavers, V. L. (2007, September). Measurement of socioeconomic status in health disparities research. Journal of the National Medical Association, 99(9) 1013-1023.

Spanier, G. B. (2010). Creating adaptable universities. Innovative Higher Education, 35(2), 91-99.

Spears, L. C. (1995). Reflections on leadership: How Robert K. Greenleaf's theory of servant-leadership influenced today's top management thinkers. New York, NY: Wiley.

Spreitzer, G. M., Perttula, K. H. \& Xin, K. (2005). Traditionality matters: An examination of the effectiveness of transformational leadership in the United States and Taiwan. Journal of Organizational Behavior, 26(3), 205-227.

Stone, G. A., Russell, R. F., \& Patterson, K. (2003). Transformational versus servant leadership: A difference in leader focus. The Leadership and Organization Development Journal, 25(4), 349361.

Townsley, M. K. (2002). Back on track: Small college turnarounds. NACUBO Business Officer, 36(3), $38-45$.

Tunçer, P. (2011). Organizational change and leadership. Journal of Court of Accounts, 80(1), 57-83.

Wells, K. (2018). Is managing getting in the way of leading? Professional Safety, 63(3), 58-59.

Williams, C. (2015). MGMT7: Principles of management. Mason, OH: South-Western.

Winstanley, D., \& Stuart-Smith, K. (1996). Policing performance: The ethics of performance management. Personnel Review, 25(6), 66-84.

Xenikou, A., \& Simosi, M. (2006). Organizational culture and transformational leadership as of business unit performance. Journal of Managerial Psychology, 21(6), 566-579. 